\title{
Pengaruh Pengembangan Karir Dan Disiplin Terhadap Kepuasan Kerja Karyawan Pada PT. Qeon Interactive - Jakarta Pusat
}

\author{
N. Lilis Suryani \\ Dosen Fakultas Ekonomi Universitas Pamulang \\ Email : dosen000437@unpam.ac.id
}

\begin{abstract}
ABSTRAK
Tujuan pada penelitian ini adalah untuk mengetahui pengaruh pengembangan karir dan disiplin terhadap kepuasan kerja karyawan pada PT. QEON INTERACTIVE.

Metode yang digunakan adalah metode deskriptif dengan pendekatan asosiatif. Teknik sampling yang digunakan adalah proporsional random sampling menggunakan dengan sampel sebanyak 70 responden. Analisis data menggunakan analisis regresi, analisis koefisien korelasi, analisis koefisien determinasi dan uji hipotesis

Hasil penelitian ini adalah pengembangan karir berpengaruh positif dan signifikan terhadap kepuasan kerja karyawan sebesar 35,7\%. Uji hipotesis secara parsial diperoleh $\mathrm{t}$ hitung $>\mathrm{t}$ tabel atau $(6,151>1,995)$, sehingga $\mathrm{H}_{0}$ ditolak dan $\mathrm{H}_{1}$ diterima artinya terdapat pengaruh positif dan signifikan antara pengembangan karir terhadap kepuasan kerja karyawan pada PT. QEON INTERACTIVE. Disiplin kerja berpengaruh positif dan signifikan terhadap kepuasan kerja karyawan sebesar 39,9\%. Uji hipotesis secara parsial diperoleh $t$ hitung $>t$ tabel atau $(6,714>1,995)$ sehingga $\mathrm{H}_{0}$ ditolak dan $\mathrm{H}_{2}$ diterima artinya terdapat pengaruh positif dan signifikan antara disiplin terhadap kepuasan kerja karyawan pada PT. QEON INTERACTIVE. Uji hipotesis simultan pengembangan karir dan disiplin berpengaruh positif dan signifikan terhadap kepuasan kerja karyawan dengan koefisien determinasi sebesar $46,7 \%$, sedangkan sisanya sebesar 53,5\% dipengaruhi faktor lain. Uji hipotesis diperoleh nilai $F$ hitung $>F$ tabel atau $(29,386>2,740)$, dengan demikian Ho ditolak dan $\mathrm{H}_{3}$ diterima. Artinya terdapat pengaruh positif dan signifikan secara simultan antara pengembangan karir dan disiplin terhadap kepuasan kerja karyawan pada PT. QEON INTERACTIVE.
\end{abstract}

Kata Kunci : Pengembangan Karir, Disiplin, Kepuasan Kerja Karyawan 


\section{PENDAHULUAN}

Manajemen merupakan alat untuk pencapaian tujuan yang diinginkan, manajemen yang tepat akan memudahkan terwujudnya tujuan perusahaan, karyawan, masyarakat. Manajemen memang memiliki berbagai macam sudut pandang dan presepsi jika disimpulkan dari berbagai definisi. Menurut Sinambela (2017:7). Manajemen adalah proses pendayagunaan seluruh sumber daya yang dimiliki organisasi untuk mencapai tujuan yang telah ditetapkan. Sedangkan menurut Hasibuan (2017:1) Manajemen adalah ilmu dan seni mengatur proses pemanfaatan sumber daya manusia dan sumber-sumber lainnya secara efektif dan efisien untuk mencapai suatu tujuan tertentu.

Suatu organisasi dapat berjalan efektif apabila fungsi-fungsi manajemen seperti perencanaan (planning), pengorganisasian (organizing), pengarahan (actuating) dan pengendalian (controlling) apabila semua itu berfungsi dengan baik, serta unsur-unsur penunjangnya tersedia dan memenuhi persyaratan. Seiring dengan kemajuan zaman maupun untuk menjawab kebutuhan konsumen, perusahaan mau tidak mau juga harus berkembang agar tetap dapat bersaing dengan perusahaan-perusahaan lainnya. Salah satunya dengan meningkatkan sumber daya manusia yang dimiliki. Pentingnya sumber daya manusia ini perlu disadari oleh semua tingkatan manajemen di perusahaan. Sumber daya manusia merupakan suatu organisasi karena sumber daya memiliki bakat, tenaga dan kreativitas yang sangat dibutuhkan oleh perusahaan untuk mencapai tujuannya.

Ada pun pengertian tentang sumber daya manusia menurut Werter dan Davis dalam Sutrisno (2017:4) menyatakan bahwa sumber daya manusia adalah pegawai yang siap, mampu, dan siaga dalam mencapai tujuan-tujuan organisasi. Sumber daya manusia tersebut haruslah kita rawat dan jaga dengan baik, karena jika hal tersebut tidak dilakukan oleh perusahaan, maka mungkin akan menyebabkan karyawan tidak mendapatkan kenyamanan dalam bekerja dan mereka memilih keluar dari perusahaan

Manajemen sumber daya manusia merupakan bagian dari manajemen keorganisasian yang berfokus pada sumber daya manusia yaitu pegawai atau karyawan yang menjadi pelaksana dan pelaku aktif dari setiap aktifitas perusahaan atau badan usaha. Untuk mencapai tujuan perusahaan diperlukan adanya pegawai yang memiliki kemampuan yang cukup untuk memajukan perusahaan. Sedangkan menurut Hasibuan (2017:10) Manajemen sumber daya manusia adalah ilmu dan seni mengatur hubungan dan peranan tenaga kerja agar efektif dan efisien membantu terwujudnya tujuan perusahaan, karyawan dan masyarakat.

Manajemen SDM bisa dilakukan dengan meningkatkan skill tertentu atau membuat mereka mempelajari hal baru sehingga mampu menjadi pribadi multitalenta yang siap sedia kapan pun perusahaan memerlukannya. Misalnya, mewajibkan SDM untuk punya soft skill berkomunikasi 
dengan klien, me-manage waktu agar bisa bekerja sesuai deadline, dan lain sebagainya. Kelemahan dalam penyediaan berbagai fasilitas tersebut akan menyebabkan keresahan sosial yang akan berdampak kepada keamanan masyarakat. Saat ini kemampuan sumber daya manusia masih rendah baik dilihat dari kemampuan intelektualnya maupun keterampilan teknis yang dimilikinya.

Sumber daya manusia tersebut harusah kita rawat dan jaga dengan baik, karena jika hal tersebut tidak dilakukan oleh perusahaan, maka mungkin akan menyebabkan karyawan tidak mendapatkan kenyamanan dalam bekerja dan mereka akan memilih keluar dari perusahaan. Jika hanya satu atau dua orang karyawan yang keluar mungkin tidak akan terlalu terasa dampaknya oleh perusahaan, namun jika hal ini tidak segera diperbaiki maka akan semakin banyak karyawan atau sumber daya manusia yang keluar dari perusahaan, dan hal ini akan berdampak sangat besar terhadap setiap kegiatan yang perusahaan sedang laksanakan. Salah satu aspek yang menyebabkan kenyamanan dalam bekerja adalah pengembangan karir bagi sumber daya manusia pada suatu organisasi atau perusahaan tersebut. Menurut Soetjipto dalam Sutrisno (2017:176), pengembangan karir berkaitan dengan penyusunan jalur karir yang merupakan urutan posisi (jabatan) yang memungkinkan diduduki oleh seorang pegawai mulai dari tingkatan terendah hingga tingkatan teratas dalam struktur organisasi.

Menurut Kaswan dalam Sinambela (2017:252), karir adalah pekerjaan dari hasil pelatihan dan atau pendidikan yang ingin dilakukan orang dalam waktu tertentu. Didalam perusahaan berbagai masalah yang berhubungan dengan pengembangan karir karyawan, diantaranya prestasi kerja karyawan yang menurun, kurangnya kesempatan karyawan untuk mempromosikan kemampuan diri dan adanya karyawan memutuskan diri untuk berhenti dari perusahaan untuk pindah ke perusahaan lain. Salah satu upaya yang dapat dilakukan untuk meningkatkan kepuasan kerja karyawan adalah deengan menciptakan iklim organisasi yang dapat menjamin kebutuhan akan kesempatan pengembangan karir yang jelas dan terbuka secara objektif bagi setiap karyawan. Artinya setiap karyawan yang prestasi kerjanya baik, akan memperoleh kesempatan karir yang baik, namun sebaliknya, karyawan yang tidak berprestasi kesempatan karirnya akan menghadapi kendala. Prestasi kerja karyawan merupakan hal yang sangat penting dalam perusahaan untuk mencapai tujuannya, sehingga perusahaan melakukan berbagai usaha untuk meningkatkannya.

Prestasi dalam bekerja merupakan salah satu kebutuhan yang ingin dicapai setiap orang dalam bekerja. Prestasi kerja karyawan tidak sama hasilnya, hal ini disebabkan karena setiap karyawan mempunyai kemampuan dan kemauan yang berbeda untuk melaksanakan pekerjaan. Karyawan dapat dikatakan memiliki prestasi kerja yang baik apabila dapat memberikan hasil terbaik untuk pekerjaannya. Artinya karyawan 
tersebut dapat mencapai atau melebihi standar atau kinerja tertentu yang ditetapkan perusahaan. Setiap perusahaan mengharapkan memiliki karyawan yang prestasi kerjanya tinggi. Prestasi kerja karyawan tinggi akan menguntungkan perusahaan dan menguntungkan karyawan, ada kemungkinan gaji atau jabatan naik. Pada kenyataannya, prestasi tinggi yang dimiliki karyawan tidak sesuai harapan perusahaan.

Perusahaan menemui prestasi kerja karyawan rendah. Akibat prestasi kerja karyawan rendah berdampak pada perusahaan dan tidak dapat memenuhi pernintaan konsumen, sehingga perusahaan menderita kerugian dan mengalami hambatan dalam perkembangannya. Sedangkan bagi karyawan yang tidak memiliki prestasi kerja akan menghambat perkembangan karir dan pendapatan menurun. Tahun 2016-2018 jumlah pendapatan PT. Qeon Interactive belum mencapai target, dilihat dari prestasi kerja karyawan yang menurun, target yang diberikan perusahaan untuk jumlah iklan yang harus tayang sebesar 3.600.000.000, di awal tahun 2016 total iklan yang tayang mencapai target perusahaan yakni sebesar 4.156.702.588, di tahun 2016 total iklan yang tayang melonjak tinggi pada bulan September sebesar 1.150.500.000. Dan pada tahun 2017 total iklan yang tayang tidak mencapai target perusahaan dan mengalami penurunan sebesar 508.831.326, lalu pada tahun 2018 juga belum mencapai target perusahaan, total iklan yang tayang mengalami penurunan yang drastis dari tahun 2016 hingga tahun 2018, pada awalnya dapat mencapai target perusahaan, lalu pada tahun 2018 mengalami penurunan yakni 486.143.885, di tahun 2016 total iklan yang tayang sudah memenuhi target perusahaan, kemudian di tahun 2017 mengalami penurunan dan tidak dapat memenuhi target perusahaan, dan di tahun 2018 mengalami penurunan yang sangat drastis dan masih belum mencapai target perusahaan. Belum tercapainya target pendapatan PT Qeon Interactive akan berdampak pada prestasi kerja karyawan, yang nantinya akan dinilai oleh atasan dan sangat berpengaruh terhadap pengembangan karir karyawan yang terhambat.

Sumber daya manusia sebagai unsur utama pada suatu lembaga memiliki peranan yang sangat besar dalam upaya mencapai tujuan yang telah ditetapkan. Peran sumber daya manusia ini kemudian berkembang mengikuti perkembangan organisasi, ilmu pengetahuan dan teknologi. Sumber daya manusia memegang peranan yang sangat menentukan karena bagaimanapun hebat dan canggihnya teknologi yang digunakan tanpa didukung oleh manusia sebagai pelayan operasionalnya, tidak akan mampu menghasilkan suatu output yang sesuai dengan tingkat efisiensi yang tinggi. Oleh karna itu pengembangan sumber daya manusia dalam suatu organisasi menjadi sangat penting, semua itu dimulai dari disiplin.

Menurut Handoko dalam Sinambela (2017:334), disiplin adalah kesediaan seseorang yang timbul dengan kesadaran sendiri untuk mengikuti peraturan-peraturan yang berlaku dalam organisasi. Menurut Singodimedjo dalam 
Sutrisno (2017:86), mengatakan disiplin adalah sikap kesediaan dan kerelaan seseorang untuk mematuhi dan mentaati norma-norma peraturan yang berlaku disekitarnya. Disiplin karyawan yang baik akan mempercepet tujuan perusahaan, sedangkan disiplin yang merosot akan menjadi penghalang dan memperlambat pencapaian tujuan perusahaan.

Disiplin yang baik mencerminkan besarnya rasa tanggung jawab seseorang terhadap tugas-tugasnya yang diberikan kepadanya. Hal ini mendorong gairah kerja, dan terwujudnya tujuan perusahaan, karyawan, dan masyarakat. Oleh karena itu, setiap manajer selalu berusaha agar pada bawahannya mempunyai disiplin yang baik. Seorang manajer dikatakan efektif dalam kepemimpinannya, jika karyawannya berdisiplin baik. Untuk memelihara dan meningkatkan kedisiplinan yang baik adalah hal yang sulit, karna banyak faktor yang mempengaruhinya. Peraturan sangat diperlukan untuk memberikan bimbingan dan penyuluhan bagi karyawan PT. Qeon Interactive dalam menciptakan tata tertib yang baik, semangat kerja, moral kerja, efisiensi, dan efektivitas kerja karyawan akan meningkat. Jika karyawan PT. Qeon Interactive tidak mematuhi peraturan-peraturan perusahaan tersebut, akan sulit mencapai tujuannya perusahaan. Kedisiplinan suatu perusahaan dikata baik, jika sebagian besar karyawan mentaati peraturan-peraturan yang ada. Kedisiplinan adalah fungsi operatif keenam (yaitu: perencanaan, pengorganisasian, pengarahan, pengawasan, pengendalian, pengadaan) dari manajer sumber daya manusia. Kedisiplinan merupakan fungsi manajemen sumber daya manusia yang terpenting, karena semakin baik disiplin karyawan, semakin tinggi prestasi kerja yang dapat di capainya. Tanpa disiplin karyawan yang baik, sulit bagi organisasi mencapai hasil yang optimal.

Lemahnya respon karyawan di PT. Qeon Interactive terhadap disiplin kerja dapat dilihat dari karyawan yang masih saja datang terlambat, tidak masuk kantor tanpa keterangan, prosedur yang telah ditetapkan oleh perusahaan masih dilanggar oleh karyawan, masih kurangnya tanggung jawab karyawan terhadap perusahaan, dilihat dari faktor tersebut karyawan masih kurang paham dengan adanya disiplin bekerja. Hasil observasi di PT. Qeon Interactive menyatakan bahwa ketidak disiplinan karyawan salah satunya tercermin dari karyawan kurangnya rasa tanggung jawab terhadap pekerjaan. Selain itu terlihat dari karyawan yang datang terlambat, tidak masuk kerja tanpa memberikan keterangan. Tahun 2016-2018 dengan keterangan sebagai berikut: jumlah karyawan, cuti, sakit, terlambat dan tanpa keterangan. Dapat dilihat bahwa karyawan yang tidak masuk kerja tidak stabil bisa dilihat dari fluktuasi kenaikan absensi periode 2016-2018. Tingkat kehadiran bervariasi pada bulan September tingkat kehadiran yang paling rendah menunjukkan 29 orang dari 70 orang karyawan. Selanjutnya pada bulan Juli dan Desember tingkat yang paling tinggi sebesar 58 orang dari 70 orang 
karyawan, dan selebihnya mengalami penurunan. Ketidakhadiran karyawan merupakan sikap dari rendahnya kedisiplinan yang dapat menurunkan tingkat kepuasan kerja. Dengan menurunnya kepuasan kerja akan menyebabkan perusahaan menjadi lambat untuk maju.

Kedisiplinan harus ditegagkan dalam suatu organisasi perusahaan. Tanpa dukungan disiplin karyawan yang baik, sulit perusahaan mewujudkan tujuannya. Jadi kedisiplinan adalah kunci keberhasilan perusahaan dalam mencapai tujuannya. Dalam melaksanakan tugas sehari-sehari dibidang karyawan adalah melatih membina karyawan. Oleh karena itu, kinerja karyawan PT. Qeon Interactive yang berkualitas sangat berpengaruh dalam terwujudnya tujuan perusahaan tersebut. Artinya makin baik pembinaan karyawan yang dilakukan, maka kinerja karyawan semakin berkualitas. Tetapi dalam pelaksanaannya, sering menemui hambatan atau masalah, sehingga mengganggu keberhasilan pelaksanaan tugasnya, dalam kondisi demikian, memerlukan bantuan dan kerjasama dengan bidang karyawan untuk memecahkan masalahnya.

Karyawan merupakan aset perusahaan yang sangat berharga yang harus dikelola dengan baik oleh perusahaan agar dapat memberikan kontribusi yang optimal. Kepuasan kerja karyawan merupakan hal penting dalam kemajuan suatu perusahaan. Menurut Mangkunegara dalam Sinambela (2017:302) bahwa kepuasan kerja adalah suatu perasaan yang menyokong atau tidak menyokong diri pegawai yang berhubungan dengan pekerjaannya maupun dengan kondisi dirinya. Kepuasan kerja adalah suatu sikap karyawan terhadap pekerjaan yang berhubungan dengan situasi kerja, kerja sama antar karyawan, imbalan yang diterima dalam kerja, dan halhal yang menyangkut factor fisik dan psikologis. Sikap terhadap pekerjaan ini merupakan hasil dari sejumlah sikap khusus individu terhadap faktor-faktor dalam pekerjaan, penyesuaian diri individu, dan hubungan social individu diluar pekerjaan sehingga menimbulkan sikap umum individu terhadap pekerjaan yang dihadapinya. Menurut Sutrisno (2017:74)

PT. Qeon Interactive adalah perusahaan yang bergerak dibidang Advertising, yang beralamat di Mid Plaza 2 Jl. Jendral Sudirman Kav 1011. Jakarta Pusat tentunya kepuasan kerja perlu diperhatikan dan ditingkatkan dengan baik. Adapun beberapa masalah di perusahaan yang menyebabkan menurunnya tingkat kepuasan kerja disebabkan terhambatnya kesempatan karyawan untuk maju, realisasi kenaikan gaji belum tercapai dengan baik, dan kesalahpahaman komunikasi sering terjadi antar pegawai dengan pihak manajemen, salah satu faktor yang menjadikan karyawan kurang puas dalam bekerja yaitu realisasi kenaikan gaji yang belum tercapai denganbaiK, Gaji karyawan PT. Qeon Interactive tahun 2016-2018, dengan total karyawan 70 karyawan. Dapat dilihat dari table diatas, bahwa untuk total gaji yang didapatkan oleh karyawan pertahunnya yakni pada awal tahun 2016 sebesar: Rp 6.193.689.027-. Lalu pada tahun 2017 mengalami peningkatan gaji 
dengan total sebesar: Rp 6.554.193.695,-. Tetapi pada tahun 2018 total gaji yang didapatkan karyawan tidak ada peningkatan dari tahun 2017, yakni total gaji tahun 2018 sebesar: Rp 6.554.193.695,-Dengan tidak ada peningkatan gaji dalam dua tahun terakhir. Permasalahan ini akan menjadi bahasan penelitian untuk melihat pengaruh kepuasan kerja karyawan dengan tidak adanya kenaikan gaji tersebut.

\section{METODE PENELITIAN}

Jenis penelitian yang digunakan adalah dengan menggunakan metode penelitian kuantitatif yang selanjutnya diolah dengan metode statistika. Penelitian ini merupakan penelitian penjelasan asosiatif yang menguji hubungan kausal antara variabel independen dan variabel dependen, Populasi dalam penelitian ini adalah populasinya adalah karyawan PT. Qeon Interactive di MID Plaza 2, JL. Jendral Sudirman Kav 10-11. Jakarta Pusat yang berjumlah 70 karyawan. Teknik pengambilan sampel yang digunakan adalah teknik sample jenuh Pengujian data digunakan uji instrumen, uji kelayakan data, uji regresi, uji koefisien determinasi dan uji hipotesis dengan uji t dan uji $F$.

\section{HASIL PENELITIAN DAN PEMBAHASAN}

\section{A. Pengujian Instrumen Data Penelitian}

\section{Uji Validitas Instrumen}

Tabel 4.1

Hasil Uji Validitas Berdasarkan Variabel Pengembangan Karir $\left(\mathbf{X}_{1}\right)$

\begin{tabular}{|c|c|c|c|c|c|}
\hline $\begin{array}{l}\text { Item } \\
\text { Kuesi } \\
\text { oner }\end{array}$ & $\begin{array}{c}\text { Chronba } \\
\text { tch } \\
\text { Alpha } \\
\text { Pengem } \\
\text { bangan } \\
\text { Karier }\end{array}$ & $\begin{array}{c}\text { Chron } \\
\text { batch } \\
\text { Alpha } \\
\text { Disipli } \\
\text { n }\end{array}$ & $\begin{array}{c}\text { Chron } \\
\text { batch } \\
\text { Alpha } \\
\text { Kinerj } \\
\text { a } \\
\text { Karya } \\
\text { wan }\end{array}$ & $\begin{array}{l}\text { Chron } \\
\text { batch } \\
\text { Alpha }\end{array}$ & $\begin{array}{l}\text { Kepu } \\
\text { tusan }\end{array}$ \\
\hline 1. & 0.399 & $\begin{array}{c}0.46 \\
6 \\
\end{array}$ & $\begin{array}{c}0.38 \\
6 \\
\end{array}$ & 0.30 & Valid \\
\hline 2. & 0.405 & $\begin{array}{c}0.52 \\
5 \\
\end{array}$ & $\begin{array}{c}0.59 \\
4 \\
\end{array}$ & 0.30 & Valid \\
\hline 3. & 0.355 & $\begin{array}{c}0.32 \\
2 \\
\end{array}$ & $\begin{array}{c}0.34 \\
2 \\
\end{array}$ & 0.30 & Valid \\
\hline 4. & 0.522 & $\begin{array}{c}0.53 \\
8\end{array}$ & $\begin{array}{c}0.50 \\
8\end{array}$ & 0.30 & Valid \\
\hline 5. & 0.819 & $\begin{array}{c}0.55 \\
5\end{array}$ & $\begin{array}{c}0.46 \\
6\end{array}$ & 0.30 & Valid \\
\hline 6. & 0.492 & $\begin{array}{c}0.40 \\
2 \\
\end{array}$ & $\begin{array}{c}0.51 \\
6\end{array}$ & 0.30 & Valid \\
\hline 7. & 0.714 & $\begin{array}{c}0.65 \\
6\end{array}$ & $\begin{array}{c}0.68 \\
6\end{array}$ & 0.30 & Valid \\
\hline 8. & 0.822 & $\begin{array}{c}0.60 \\
3\end{array}$ & $\begin{array}{c}0.56 \\
8\end{array}$ & 0.30 & Valid \\
\hline 9. & 0.828 & $\begin{array}{c}0.41 \\
2\end{array}$ & $\begin{array}{c}0.70 \\
3\end{array}$ & 0.30 & Valid \\
\hline 10. & 0.392 & $\begin{array}{c}0.60 \\
4\end{array}$ & $\begin{array}{c}0.47 \\
7\end{array}$ & 0.30 & Valid \\
\hline
\end{tabular}

Sumber: Data Primer diolah, 2019

Berdasarkan data tabel di atas, semua variabel diperoleh nilai Chronbatch Alpha lebih besar dari 0,30, dengan demikian maka semua item kuesioner dinyatakan valid. Untuk itu kuesioner yang digunakan layak untuk diolah

\section{Uji Reliabilitas Instrumen} Tabel 4.2

Hasil Uji Reliabilitas Variabel Independen dan Dependen

\begin{tabular}{|c|c|c|c|l|}
\hline No. & Variabel & $\begin{array}{c}\text { Coeficient } \\
\text { Alpha }\end{array}$ & $\begin{array}{c}\text { Standar } \\
\text { Chronbach } \\
\text { Alpha }\end{array}$ & Keputusa \\
\hline 1 & $\begin{array}{c}\text { Pengembangan } \\
\text { Karir (X1) }\end{array}$ & 0.771 & 0.60 & Reliabel \\
\hline 2 & Disiplin (X2) & 0.682 & 0.60 & Reliabel \\
\hline 3 & $\begin{array}{c}\text { Kepuasan } \\
\text { Kerja } \\
\text { Karyawan (Y) }\end{array}$ & 0.710 & 0.60 & Reliabel \\
\hline
\end{tabular}


Sumber: Data Primer diolah, 2019.

Berdasarkan hasil pengujian pada tabel di atas, menunjukkan bahwa variabel pengembangan karir $\left(\mathrm{X}_{1}\right)$, disiplin $\left(\mathrm{X}_{2}\right)$ dan kepuasan kerja karyawan $(\mathrm{Y})$ dinyatakan reliabel, hal itu dibuktikan dengan masing-masing variabel memiliki nilai coeficien Alpha lebih besar dari Chronbath Alpha 0,60.

\section{Pengujian Asumsi Klasik (Uji Prasyarat Data) \\ a. Uji Normalitas \\ Tabel 4.3 \\ Hasil Uji Normalitas Dengan \\ Kolmogorov-Smirnov Test \\ Tests of Normality \\ Kolmogorov- \\ Smirnov $^{\mathrm{a}}$ Shapiro-Wilk \\ Statis D $\mathrm{Si}$ Statis d $\mathrm{di}$

\begin{tabular}{ll|l|r|r|r|r} 
& tic & f & g. & tic & f & g. \\
\hline Kepuas & .102 & 7 & .07 & .962 & 7 & .03 \\
an & & 0 & 0 & & 0 & 2 \\
Kerja & & & & & & \\
Karyaw & & & & & & \\
an (Y) & & & & & & \\
\hline
\end{tabular} \\ a. Lilliefors Significance Correction \\ Sumber: Data Primer diolah, 2019. \\ Berdasarkan hasil pengujian pada tabel di atas, diperoleh nilai signifikansi $\alpha=0,070$ dimana nilai tersebut lebih besar dari nilai $\alpha=0,050$ atau $(0,070>$ 0,050). Dengan demikian maka asumsi distribusi persamaan pada uji ini adalah normal.}

\section{b. Uji Multikolinearitas \\ Tabel 4.4}

Hasil Pengujian Multikolinearitas Dengan Collinearity Statistic
Kepuasan Kerja Karyawan

Sebagai Variabel Dependen

\begin{tabular}{|l|c|c|}
\hline \multirow{2}{*}{ Variabel } & \multicolumn{2}{|c|}{ Colinerity Statistics } \\
\cline { 2 - 3 } & Tolerance & VIF \\
\hline $\begin{array}{l}\text { Pengembangan } \\
\text { Karir (X1) }\end{array}$ & 0.613 & 1.631 \\
\hline Disiplin (X2) & 0.613 & 1.631 \\
\hline
\end{tabular}

Sumber: Data Primer diolah, 2019

Berdasarkan hasil pengujian multikolinieritas pada tabel di atas diperoleh nilai tolerance masingmasing variabel bebas yaitu pengembangan karir sebesar 0,613 dan disiplin sebesar 0,613 , dimana kedua nilai tersebut kurang dari 1, dan nilai Variance Inflation Factor (VIF) variabel pengembangan karir sebesar 1,631 serta disiplin sebesar 1,631 dimana nilai tersebut kurang dari 10. Dengan demikian model regresi ini tidak ada multikolinearitas.

\section{c. Uji Autokorelasi}

Tabel 4.5

Uji Durbin-Watson

Model Summary ${ }^{b}$

\begin{tabular}{|c|c|c|c|c|c|}
\hline $\begin{array}{l}\text { Mo } \\
\text { del }\end{array}$ & $\mathrm{R}$ & $\begin{array}{c}\mathrm{R} \\
\text { Squ } \\
\text { are }\end{array}$ & $\begin{array}{l}\text { Adjus } \\
\text { ted R } \\
\text { Squar } \\
\mathrm{e} \\
\end{array}$ & $\begin{array}{l}\text { Std. } \\
\text { Error } \\
\text { of the } \\
\text { Estim } \\
\text { ate }\end{array}$ & $\begin{array}{c}\text { Durb } \\
\text { in- } \\
\text { Wats } \\
\text { on }\end{array}$ \\
\hline 1 & $\begin{array}{r}.68 \\
4^{\mathrm{a}}\end{array}$ & .467 & .451 & 2.669 & 1.907 \\
\hline
\end{tabular}

a. Predictors: (Constant), Disiplin (X2),

Pengembangan Karir (X1)

b. Dependent Variable: Kepuasan

Kerja Karyawan (Y)

Sumber: Data Primer diolah, 2019.

Berdasarkan hasil pengujian pada tabel di atas, model regresi ini tidak ada autokorelasi, hal ini dibuktikan dengan nilai 
Durbin-Watson sebesar 1.907 yang berada diantara interval $1.550-2.460$.

\section{d. Uji Heteroskedastisitas}

Tabel 4.6

Hasil Pengujian

\section{Heteroskesdastisitas Dengan $\boldsymbol{U} \boldsymbol{j i}$ Glejser}

\section{Coefficients $^{\mathrm{a}}$}

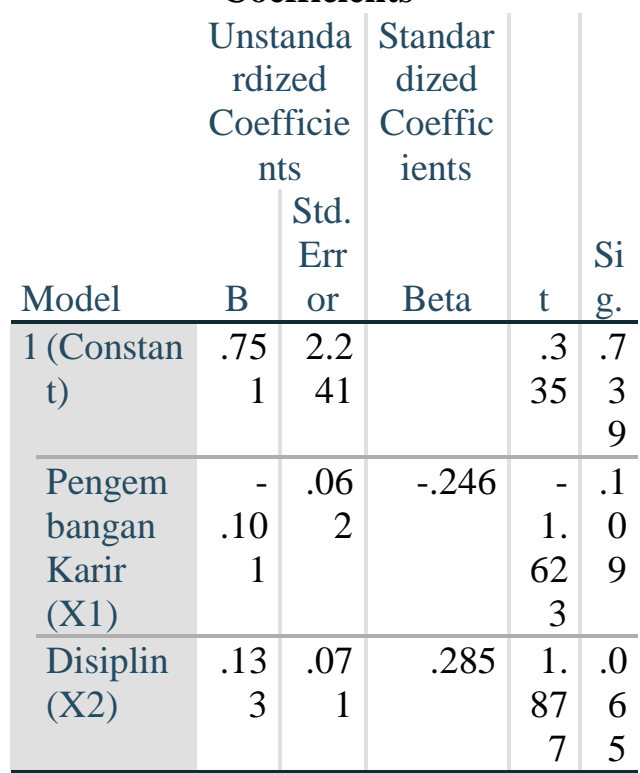

a. Dependent Variable: RES2

Sumber: Data Primer diolah, 2019.

Berdasarkan hasil pengujian pada tabel di atas, glejser test model pada variabel pengembangan karir $\left(\mathrm{X}_{1}\right)$ diperoleh nilai probability signifikansi (Sig.) sebesar 0,109 dan disiplin $\left(\mathrm{X}_{2}\right)$ diperoleh nilai probability signifikansi (Sig.) sebesar 0,65 dimana keduanya nilai signifikansi (Sig.) > 0,05. Dengan demikian regression model pada data ini tidak ada gangguan heteroskesdastisitas, sehingga model regresi ini layak dipakai sebagai data penelitian.

\section{B. Analisis Verifikatif}

\section{Analisis Regresi}

Tabel 4.7

Hasil Pengolahan Regresi

Berganda Variabel Pengembangan

Karir $\left(\mathbf{X}_{1}\right)$ dan Disiplin $\left(\mathbf{X}_{2}\right)$

Terhadap Kepuasan Kerja Karyawan (Y)

Coefficients $^{\mathbf{a}}$

Unstanda Standar rdized dized

Coefficie Coeffic nts ients

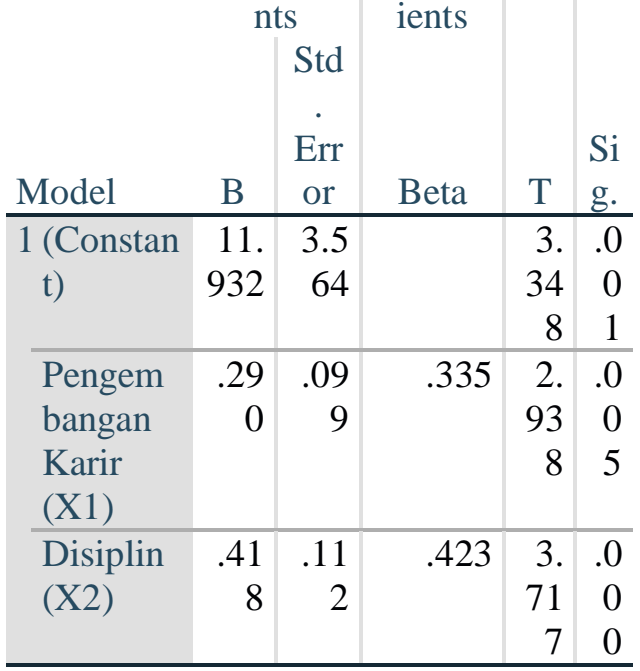

a. Dependent Variable: Kepuasan Kerja Karyawan (Y)

Sumber: Data Primer diolah, 2019

Berdasarkan hasil analisis perhitungan regresi pada tabel di atas, maka dapat diperoleh persamaan regresi $\mathrm{Y}$ $=11,932+0,290 \mathrm{X}_{1}+0,418 \mathrm{X}_{2}$.

\section{Analisis Koefisien Korelasi} (r)

Tabel 4.8

Hasil Analisis Koefisien Korelasi

Secara Simultan Antara Variabel

Pengembangan Karir $\left(X_{1}\right)$ dan

Disiplin $\left(\mathbf{X}_{2}\right)$ Terhadap

Kepuasan Kerja Karyawan (Y) 


\begin{tabular}{|c|c|c|c|c|}
\hline \multicolumn{5}{|c|}{ Model Summary } \\
\hline $\begin{array}{l}\text { Mode } \\
1\end{array}$ & $\mathrm{R}$ & $\begin{array}{c}\mathrm{R} \\
\text { Squar } \\
\mathrm{e}\end{array}$ & $\begin{array}{c}\text { Adjuste } \\
\text { d R } \\
\text { Square }\end{array}$ & $\begin{array}{l}\text { Std. } \\
\text { Error of } \\
\text { the } \\
\text { Estimat } \\
\mathrm{e}\end{array}$ \\
\hline 1 & .684 & .467 & .451 & 2.669 \\
\hline
\end{tabular}

a. Predictors: (Constant), Disiplin (X2), Pengembangan Karir (X1)

Sumber : Data Primer diolah, 2019.

Berdasarkan pada hasil pengujian pada tabel di atas, diperoleh nilai $R$ (koefisien korelasi) sebesar 0,684 artinya variabel pengembangan karir $\left(\mathrm{X}_{1}\right)$ dan disiplin (X2) mempunyai tingkat pengaruh atau hubungan yang kuat terhadap kepuasan kerja karyawan (Y).

\section{Analisis} Determinasi ( $R$ Square)

Tabel 4.9

Hasil Analisis Koefisien

Determinasi Secara Simultan

Antara Variabel Pengembangan

Karir $\left(X_{1}\right)$ dan Disiplin (X2)

Terhadap Kepuasan Kerja

Karyawan (Y)

Model Summary

\begin{tabular}{|c|c|c|c|c|}
\hline $\begin{array}{l}\text { Mode } \\
1\end{array}$ & $\mathrm{R}$ & $\begin{array}{c}\mathrm{R} \\
\text { Squar } \\
\mathrm{e}\end{array}$ & $\begin{array}{c}\text { Adjuste } \\
\text { d R } \\
\text { Square }\end{array}$ & $\begin{array}{l}\text { Std. } \\
\text { Error of } \\
\text { the } \\
\text { Estimat } \\
\mathrm{e}\end{array}$ \\
\hline 1 & .684 & .467 & .451 & 2.669 \\
\hline
\end{tabular}

a. Predictors: (Constant), Disiplin (X2), Pengembangan Karir (X1)

Sumber: Data Primer diolah, 2019.

Berdasarkan pada hasil pengujian pada tabel di atas, diperoleh nilai $R$-square sebesar 0,467 maka dapat disimpulkan bahwa variabel pengembangan karir $\left(\mathrm{X}_{1}\right)$ dan disiplin (X2) berpengaruh terhadap variabel kepuasan kerja karyawan (Y) sebesar $46,7 \%$ sedangkan sisanya sebesar $53,5 \%$ dipengaruhi oleh faktor lain yang tidak dilakukan penelitian.

\section{Pengujian Hipotesis}

Tabel 4.10

\begin{tabular}{|c|c|c|c|c|c|}
\hline \multicolumn{6}{|c|}{$\begin{array}{c}\text { Hasil Hipotesis (Uji F) Simultan } \\
\text { ANOVA }\end{array}$} \\
\hline Model & $\begin{array}{l}\text { Sum } \\
\text { of } \\
\text { Squar } \\
\text { es }\end{array}$ & $\begin{array}{l}\mathrm{d} \\
\mathrm{f}\end{array}$ & $\begin{array}{l}\text { Mean } \\
\text { Squar } \\
\text { e }\end{array}$ & $\mathrm{F}$ & Sig \\
\hline $\begin{array}{l}1 \text { Regress } \\
\text { ion }\end{array}$ & $\begin{array}{r}418.5 \\
86 \\
\end{array}$ & 2 & $\begin{array}{r}209.2 \\
93 \\
\end{array}$ & $\begin{array}{r}29.3 \\
86\end{array}$ & $\begin{array}{r}.00 \\
0^{\mathrm{b}}\end{array}$ \\
\hline $\begin{array}{l}\text { Residua } \\
1\end{array}$ & $\begin{array}{r}477.1 \\
86\end{array}$ & $\begin{array}{l}6 \\
7\end{array}$ & 7.122 & & \\
\hline Total & $\begin{array}{r}895.7 \\
71\end{array}$ & $\begin{array}{l}6 \\
9\end{array}$ & & & \\
\hline
\end{tabular}

a. Dependent Variable: Kepuasan

Kerja Karyawan (Y)

b. Predictors: (Constant), Disiplin

(X2), Pengembangan Karir (X1)

Sumber: Data Primer diolah, 2019.

Berdasarkan pada hasil pengujian pada tabel di atas diperoleh nilai $F_{\text {hitung }}>\mathrm{F}_{\text {tabel }}$ atau $(29,386>2,740)$, hal ini juga diperkuat dengan $\rho$ value < Sig.0,05 atau $(0,000<0,05)$. Dengan demikian maka $\mathrm{H}_{0}$ ditolak dan $\mathrm{H}_{3}$ diterima, hal ini menunjukkan bahwa terdapat pengaruh positif dan signifikan secara simultan antara pengembangan karir dan disiplin terhadap kepuasan kerja karyawan pada PT. Qeon Interactive

\section{KESIMPULAN DAN SARAN}

\section{A. Kesimpulan}


1. Pengembangan karir $\left(X_{1}\right)$ berpengaruh positif dan signifikan terhadap kepuasan kerja karyawan (Y) dengan persamaa regresi $\mathrm{Y}=19,243+$ $0,518 \mathrm{X}_{1}$, nila koefisien korelasi sebesar 0,598 artinya kedua variabel memiliki pengaruh yang sedang dengan koefisien determinasi sebesar $35,7 \%$. Uji hipotesis diperoleh $\mathrm{t}$ hitung $>\mathrm{t}$ tabel atau $(6,151>1,995)$, hal ini diperkuat dengan probability signifikansi $0,000<$ 0,05, dengan demikian $\mathrm{H}_{0}$ ditolak dan $\mathrm{H}_{1}$ diterima artinya terdapat pengaruh positif dan signifikan antara pengembangan karir terhadap kepuasan kerja karyawan pada PT. Qeon Interactive di Jakarta Pusat.

2. Disiplin $\left(X_{2}\right)$ berpengaruh positif dan signifikan terhadap kepuasan kerja karyawan (Y) dengan persamaa regresi $\mathrm{Y}=$ $15,135+0,624 \mathrm{X}_{2}, \quad$ nilai koefisien korelasi sebesar 0,631 artinya kedua memiliki pengaruh yang kuat dengan koefisien determinasi sebesar $39,9 \%$. Uji hipotesis diperoleh t hitung > t tabel atau $(6,714>$ 1,995), hal ini diperkuat dengan probability signifikansi $0,000<0,05$, dengan demikian $\mathrm{H}_{0}$ ditolak dan $\mathrm{H}_{2}$ diterima artinya terdapat pengaruh positif dan signifikan antara disiplin $\left(\mathrm{X}_{2}\right)$ terhadap kepuasan kerja karyawan (Y) pada PT. Qeon Interactive di Jakarta Pusat.

3. Pengembangan karir $\left(X_{1}\right)$ dan disiplin $\left(\mathrm{X}_{2}\right)$ berpengaruh positif dan signifikan terhadap kepuasan kerja karyawan (Y) dengan persamaan regresi $\mathrm{Y}=$ $11,932+0,290 X_{1}+0,418 X_{2}$. Nilai koefisien korelasi diperoleh sebesar 0,684 artinya variabel bebas dengan variabel terikat memiliki pengaruh yang kuat dengan koefisien determinasi atau pengaruh secara simultan sebesar $46,7 \%$ sedangkan sisanya sebesar $53,5 \%$ dipengaruhi faktor lain. Uji hipotesis diperoleh nilai $F$ hitung $>F_{\text {tabel }}$ atau $(29,386>$ 2,740), hal tersebut juga diperkuat dengan probability signifikansi $0,000<0,05$. Dengan demikian $\mathrm{H}_{0}$ ditolak dan $\mathrm{H}_{3}$ diterima. Artinya terdapat pengaruh positif dan signifikan secara simultan antara pengembangan karir dan disiplin terhadap kepuasan kerja karyawan pada PT. Qeon Interactive di Jakarta Pusat.

\section{B. Saran}

1. Variabel pengembangan karir (X1) pernyataan yang paling lemah adalah pernyataan nomor 10 yaitu kesempatan untuk berkembang dalam karir terbuka bagi seluruh karyawan. Dimana hanya mencapai score sebesar 3,61. Untuk lebih baik lagi maka perusahaan harus memberikan kesempatan bagi seluruh karyawan untuk mengembangkan karir nya karena dengan perusahaan memberikan kesempatan kepada karyawan untuk mengembangkan karirnya, karyawan akan loyalitas terhadap perusahaan dan 
karyawan pun menjadi semangat, giat dalam bekerja.

2. Variabel disiplin (X2), pernyataan yang paling lemah adalah pernyataan nomor 5 yaitu bertanggung jawab terhadap tugas dan pekerjaan yang diperintahkan oleh pimpinan dimana hanya mencapai score sebesar 3,66. Untuk lebih baik lagi perusahaan harus lebih memperhatikan \& mengevaluasi kembali tugas/laporan yang sudah diberikan oleh masing-masing pimpinan terhadap karyawan, apakah karyawan tersebut sudah bertanggung jawab atas kerjaan mereka masingmasing, serta menerapkan aturan yang sudah dibuat perusahaan sehingga karyawan dapat memiliki rasa tanggung jawab yang lebih terhadap pekerjaan mereka masingmasing.

3. Variabel kepuasan kerja karyawan (Y), pernyataan yang paling lemah adalah pernyataan nomor 3. yaitu gaji yang diberikan perusahaan memenuhi kebutuhan dasar. dimana hanya mencapai score sebesar 3,69. Untuk lebih baik lagi perusahaan harus lebih memperhatikan gaji yang diberikan kepada karyawan, gaji yang diberikan perusahaan setidaknya sudah sesuai dengan Upah Minimum Jakarta dan juga perusahaan memberikan kenaikan gaji setiap tahunnya kepada karyawan.
4. Kontibusi pengaruh atau nilai determinasi secara simultan antara pengembangan karir dan disiplin terhadap kepuasan kerja karyawan sebesar 45,0\%, nilai ini masih bisa ditingkatkan dengan secara selektif dapat memprioritaskan pesanan pelanggan yang harus dipenuhi dan kondisi masingmasing variabel bebas harus ditingkatkan secara signifikan. Oleh karenanya disarankan kepada penelitian berikutnya agar melakukan penelitian yang relevan dengan cara memperbaiki indikator yang masih tidak baik atau dengan menambah indikator pertanyaan dan jumlah responden penelitian sehingga akan dapat lebih diketahui variabel yang paling memberikan kontribusi positif bagi perusahaan.

\section{DAFTAR PUSTAKA}

A.A Anwar Prabu Mangkunegara, "Sumber Kerangka Berfikir Kinerja". Gramedia, Jakarta Selatan, 2013.

Alghifari. 2014. "Analisis Regresi Untuk Bisnis dan Ekonomi". BPFEYogyakarta.

Andi Supangat, "Statistika dalam Kajian Deskriftif, Inferensi dan Non Parametric", Edisi Pertama, Kencana Prenada Media Group, Jakarta, 2014.

Arikunto, Suharsimi, "Prosedur Penelitian Suatu Pendekatan Praktek", PT. Rineka Cipta, Jakarta, 2015.

Eko, Widodo Suparno. 2015. "Manajemen Pengembangan 
Sumber Daya Manusia".

Pustaka Pelajar, Yogyakarta

Ghozali, Imam. 2016. "Aplikasi

Analisis Multivariete Dengan

Program IBM SPSS 23 (Edisi

8)". Cetakan ke VIII. Badan

Penerbit

Universitas

Diponegoro, Semarang.

Hasibuan, Malayu S.P. 2017.

"Manajemen Sumber Daya

Manusia" . PT Bumi Aksara, Jakarta.

Hani, T. Handoko. 2014. "Manajemen Personalia dan Sumber Daya Manusia". BPFE-Yogyakarta, Yogyakarta

Rivai, Veithzal, "Manajemen Sumber Daya Manusia Untuk Perusahaan", Raja Grafindo Persada, Jakarta, 2014.

Santoso, Singgih, "SPSS Statistik

Parametik" Cetakan Kedua,

PT. Elek Media, 2015.

Sedarmayanti. 2013. "Manajemen

Sumber Daya Manusia".

Refika Aditama, Bandung.

Simamora, Henry. 2014.

"Manajemen Sumber Daya
Manusia”. Bagian Penerbitan

Sekolah Tinggi Ilmu Ekonomi

YKPN, Yogyakarta.

Sinambela, Lijan Poltak. 2017.

"Manajemen Sumber Daya

Manusia".PT Bumi Aksara,

Yogayakatarta

Sudjana, "Metode Statistika", Edisi

Keenam, Tarsito, Bandung, 2011.

Sugiyono. 2015. "Metode Penelitian Kuantitatif Kualitatif dan R \& D”, Penerbit CV. Alfabeta, Bandung.

Sunarsi, D. (2018). Pengaruh Gaya Kepemimpinan dan Disiplin Kerja Terhadap Kinerja Karyawan Pada CV. Usaha Mandiri Jakarta. JENIUS, 1(2).

Sutrisno, Edi 2017. "Manajemen Sumber Daya Manusia". Edisi Pertama, Cetak Ke Sepuluh. Kencana, Jakarta.

Wibowo. 2016. "Manajemen Kinerja". PT Raja Grafindo Persada, Jakarta. 